\title{
UPAYA MENINGKATKAN HASIL BELAJAR SISWA MELALUI METODE ROLEPLAY PADA MATA PELAJARAN PENDIDIKAN AGAMA ISLAM MATERI SHALAT BERJAMAAH SMP NEGERI 6 SITUBONDO TAHUN PELAJARAN 2018/2019
}

\author{
Moch. Nur Qomari ${ }^{1}$ \\ ${ }^{1}$ SMPN 6 Situbondo \\ Correspondence Email: qomari_muh@gmail.com
}

Received: Apr 15, $2020 \quad$ Revised: Apr 19, $2020 \quad$ Accepted: Apr 22, 2020

\begin{abstract}
ABSTRAK
Upaya Peningkatan Hasil Belajar Pendidikan Agama Islam Materi Shalat Bejamaah Menggunakan Metode Role Play pada siswa Kelas VIIB SMP Negeri 6 Situbondo Tahun pelajaran 2018/2019. Masing-masing siklus terdiri atas beberapa tahap yaitu: tahap perencanaan, tindakan, observasi dan refleksi.

Data penelitian yang terkumpul terutama hasil belajar siswa pada materi sholat berjamaah dianalisis menggunakan metode deskriptif prosentase. Indikator kinerja dikatakan berhasil jika secara individual siswa mencapai nilai 70 sesuai dengan standar yang ditetapkan oleh madrasah. Secara klasikal jika siswa mencapai nilai 70 sebanyak $85 \%$ dari seluruh siswa yang hadir.

Hasil penelitian menunjukkan bahwa ada peningkatan hasil belajar siswa pada materi sholat berjamaah. Nilai siswa sebelum tindakan rata-rata kelas 59 dengan prosentase hanya 30\% Meningkat pada tindakan siklus 1 rata-rata kelas menjadi 71,5 dengan prosentase ketuntasan $66,6 \%$ dari seluruh siswa yang hadir. Pada siklus berikutnya yakni siklus 2 rata-rata kelas menjadi 80,1 Dengan ketuntasan secara klasikal mencapai $93.3 \%$

Dari data di atas dapat disimpulkan bahwa pembelajaran dengan menggunakan metode role play pada materi sholat berjamaah mata pelajaran Pendidikan Agama Islam dapat meningkatkan hasil belajar siswa. Karena pembelajaran dengan menggunakan metode ini siswa dapat mempraktikan langsung dan nyata. Berdasarkan hasil penelitian ini diharapkan akan menjadi bahan informasi dan masukan bagi tenaga pengajar khusunya pengampu mata pelajaran Pendidikan Agama Islam untuk lebih meningkatkan kualitas pembelajaran dengan menggunakan metode- metode pembelajaran yang aktif, inovatif, krestif dan menyenangkan.
\end{abstract}

Kata Kunci : Hasil Belajar, Metode Role Play, materi Sholat Berjamaah 


\section{PENDAHULUAN}

Dalam lingkup pendidikan, guru menjadi perantara pengetahuan. Guru menerjemahkan ilmu pengetahuan menjadi sebuah paket informasi yang menyenangkan sehingga siswa mudah menyerapnya. Guru menciptakan pelajaran yang kreatif agar pengetahuan menjadi sesuatu yang menarik. ${ }^{1}$

Upaya meningkatkan keberhasilan pembelajaran, merupakan tantangan yang selalu dihadapi oleh setiap orang yang berkecimpung dalam profesi keguruan dan kependidikan. Banyak upaya yang dilakukan, namun apa yang telah dicapai belum sepenuhnya memberikan kepuasan sehingga menuntut renungan, pemikiran dan kerja keras untuk memecahkan masalah yang dihadapi.

Salah satu upaya untuk lebih meningkatkan keberhasilan belajar siswa diantaranya adalah melalui upaya memperbaiki proses pembelajaran. Dalam perbaikan proses pembelajaran ini peranan guru sangat penting, yaitu menetukan metode pembelajaran yang tepat. Oleh karena sasaran proses pembelajaran adalah siswa belajar, maka dalam menetapkan metode pembelajaran, fokus perhatian guru adalah upaya membelajarkan siswa.

Guru seharusnya mampu menentukan metode pembelajaran yang dipandang dapat membelajarkan siswa melalui proses pembelajaran yang dilaksanakan, agar tujuan pembelajaran dapat tercapai secara efektif, dan hasil belajar pun diharapkan dapat lebih ditingkatkan. Metode pembelajaran dapat ditentukan oleh guru dengan memperhatikan tujuan dan materi pembelajaran. Pertimbangan pokok dalam menentukan metode pembelajaran terletak pada keefektifan pembelajaran. Tentu saja orientsi guru adalahbkepada siswa belajar. Jadi, metode pembelajaran yang digunakan pada dasarnya hanya berfungsi sebagi agar siswa belajar.

Metode pembelajaran pada umumnya menggunakan pendekatan sistem (system approach). Dengan pendekatan ini pembelajaran dipandang sebagai suatu sistem yang mempunyai sejumlah komponen yang saling berinteraksi dan berhubungan dalam rangka mencapai tujuan. Komponen tersebut diantaranya adalah materi, metode, alat, dan evaluasi. Semua komponen itu saling berhubungan dalam rangka mencapai tujuan pembelajaran. Guru dalam menggunakan metode pembelajaran, perlu mempertimbangkan faktor-faktor kesesuaian antara metode pembelajaran dengan tujuan pembelajaran, materi pembelajaran, kemampuan guru, kondisi siswa, sumber dan fasilitas yang tersedia, situasi kondisi pembelajaran, dan waktu yang tersedia. 104|J UR N A L I K A V O L 9 No. 1 J U N I 20021 
Disamping kesesuaian metode pembelajaran dengan faktor tersebut, dalam praktek pembelajaran guru harus memahami fungsi dan keguanaan serta batas-batas penggunaan suatu metode pembelajaran. Hal ini jelas merupakan tuntutan yang dihadapi dalam penyelenggaraan proses pembelajaran.

Model pembelajaran Pendidikan Agama Islam yang terjadi selama ini terjadi masih menggunakan metode konvensional. Metode tersebut akan membuat kejenuhan siswa dalam memahami suatu materi karena terkesan monoton. Materi Pendidikan Agama Islam adalah materi yang berhubungan dengan ibadah yang akan mempengaruhi tingkat pemahaman ibadah siswa sehari-hari sehingga variasi metode dan media mutlak diperlukan dalam pembelajaran Pendidikan Agama Islam. Salah satu metode yang tepat digunakan oleh guru adalah metode Role Play. Metode Role Play atau bermain peran adalah salah satu bentuk permainan pendidikan (educational games) yang dipakai untuk menjelaskan perasaan, sudut pandang dan cara berfikir orang lain (membayangkan diri sendiri seperti dalam keadaan orang lain).

Metode sosiodrama atau Role Playing dapat dikatakan sama artinya dan dalam pemakaiannya sering disalah gantikan. Sosiodrama pada dasarnya mendramatisasi tingkah laku dalam hubungan dengan masalah sosial. Metode bermain peran adalah metode yang meletakkan interalisasi antara 2 siswa atau lebih tentang topik atau situasi. Siswa melakukan peran masing-masing sesuai pokok yang ia perankan. Mereka berinteraksi dengan sesama mereka melakukan peran terbuka. (Ambarjaya, Beni S. 56; 2008)

Langkah-langkah pelaksanaan metode Role Play

Dalam menggunakan metode role play, guru hendaknya memperhatikan langkah-langkah berikut :

1. Menetapkan dahulu masalah-masalah sosial yang menarik perhatian siswa untuk membahasnya

2. Menceritakan kepada kelas isi dari masalah-masalah dalam konteks akur sebuah cerita

3. Menetapkan siswa yang dapat atau yang bersedia untuk memainkan perannya di depan kelas

4. Memberi penjelasan kepada pendengar atau penonton mengenai peranan mereka pada waktu sosiodrama sedang berlangsung.

5. Memberi kesempatan kepada para pelaku untuk berunding beberapa menit sebelum mereka memainkan peran

6. Mengakhiri sosiodrama atau bermain peran dengan diskusi kelas untuk bersama-sama memecahkan masalah yang muncul dalam sosiodrama tersebut 
7. Menilai hasil bermain peran sebagai bahan pertimbangan lebih lanjut.

Oleh karena itu dalam pembelajaran Pendidikan Agama Islam terutama pokok bahasan Sholat berjamaah peniliti ingin mencoba melakukan suatu model pembelajaran di luar kelas atau dengan dengan metode Role Play sebagai teknik belajar pada materi pokok Sholat berjamaah. Pembelajaran ini diharapkan akan mengubah pola pikir siswa sehingga Pendidikan Agama Islam menjadi pelajaran yang menyenangkan. Selain itu, juga untuk menciptakan peserta didik yang terampil dalam bidang ibadah terutama ibadah Sholat yang wajib dilakukan oleh setiap orang Islam.

\section{METODE PENELITIAN}

\section{A. Tempat dan Waktu Penelitian}

1. Tempat penelitian

Penelitian tindakan kelas ini bertempat di SMP Negeri 6 Situbondo yang berada di kota Situbondo tepatnya di desa Kndang Kecamatan oleaan Kabupaten Situbondo.

\section{Tabel 3.1 Jadwal Penelitian}

\begin{tabular}{|c|c|c|c|c|c|c|c|c|c|}
\hline \multirow{3}{*}{ No } & \multirow{3}{*}{ Kegiatan } & \multicolumn{4}{|c|}{ Nopember } & \multicolumn{4}{|c|}{ Desember } \\
\hline & & \multicolumn{8}{|c|}{ Minggu ke } \\
\hline & & $\mathbf{1}$ & 2 & 3 & 4 & 1 & 2 & 3 & 4 \\
\hline 1 & Persiapan & & $\mathrm{x}$ & & & & & & \\
\hline 2 & Pelaksanaan Penelitian & & & $\mathrm{x}$ & $\mathrm{x}$ & $\mathrm{x}$ & & & \\
\hline 3 & Pengolahan Data & & & & & & $\mathrm{x}$ & & \\
\hline 4 & Penyusunan Skripsi & & & & & & & $\mathrm{x}$ & \\
\hline
\end{tabular}

\section{B. Subjek Penelitian}

Adapun subek penelitian yang dikenai tindakan adalah siswa kelas VII B SMP Negeri 6 Situbondo yang terdiri dari 30 siswa. Peneliti mengambil sampel siswa kelas VII B di SMP Negeri 6 Situbondo dengan alasan dikelas ini banyak yang belum memenuhi kriteria ketuntasan minimal dan keaktifan belajar yang kurang maksimal.

\section{Desain Penelitian}

Penelitian ini menggunakan metode penelitian tindakan kelas (classroom Action Research). Pengertian penelitian tindakan kelas adalah penelitian yang mengkombinasikan prosedur penelitian dengan tindakan substantif, suatu tindakan yang dilakukan dalam disiplin inquiri, atau suatu usaha seseorang untuk memahami apa yang sedang terjadi, sambil terlibat dalam sebuah proses perbaikan dan perubahan.

Tindakan ini dilaksanakan dengan tujuan untuk memperbaiki permasalahan belajar yang terjadi di SMP Negeri 6 Situbondo yang selama ini kurang maksimal 
khususnya pada mata pelajaran Pendidikan Agama Islam. Tindakan akan dilakukan sebanyak 2 siklus dikarenakan wakatu yang tersedia cukup terbatas.

Masing-masing siklus terdiri dari 4 tahapan yakni; perencanaan, pelaksanaan, Observasi dan refleksi. Adapun alur penelitian tindakan kelas ini dapat dilihat pada gambar berikut :

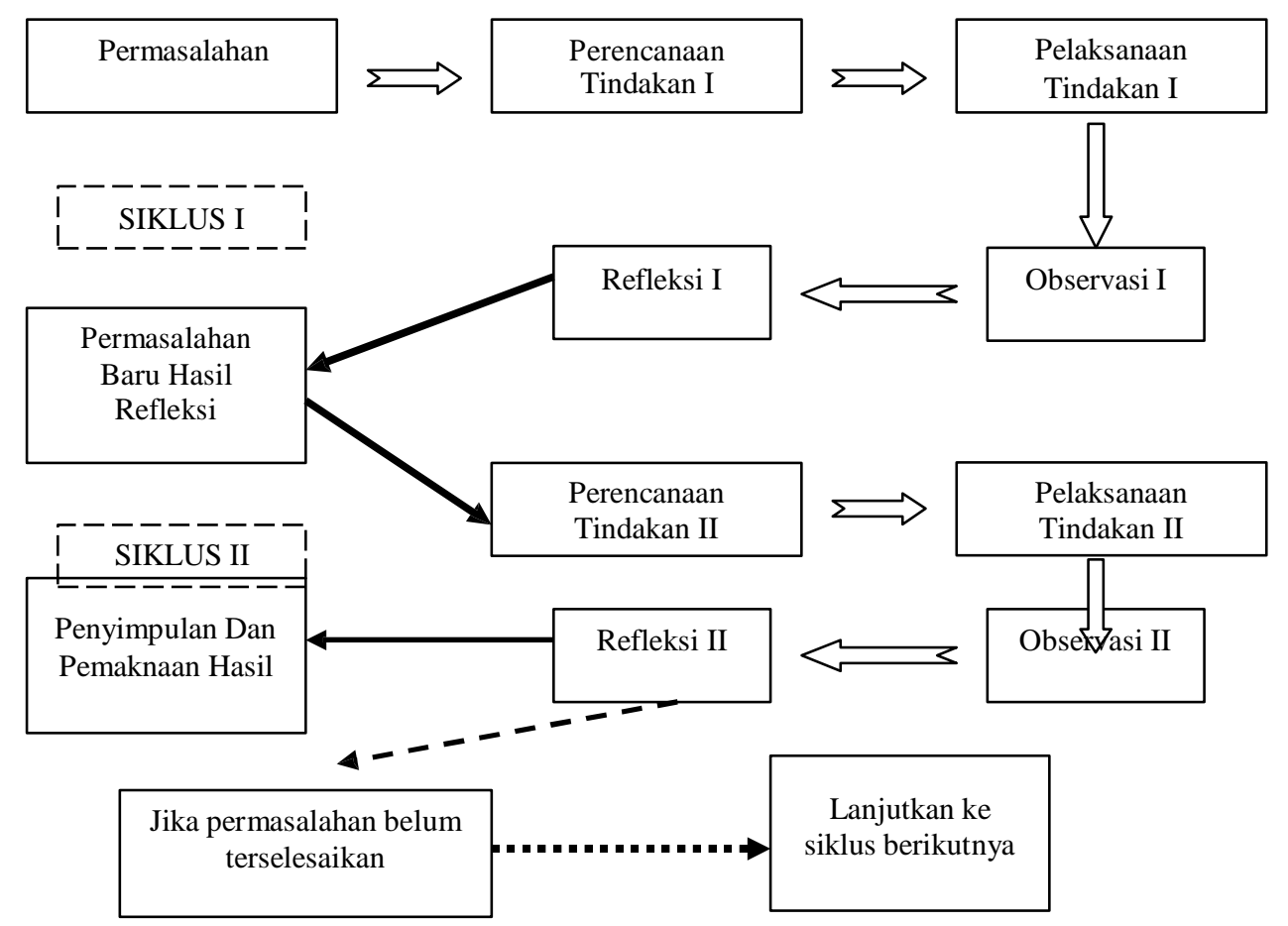

Mohammad Asrori. Penelitian Tindakan Kelas. Bandung : CV Wacana Prima, 2008. hlm.

Prosedur PTK sebenarnya terdiri dari 2 siklus atau lebih. Setiap siklus dilaksanakan sesuai dengan perubahan yang ingin dicapai. Maka dalam penelitian tindakan ini direncanakan 2 siklus dengan prosedur: 1) perencanaan, 2) pelaksanaan tindakan, 3) observasi, 4) refleksi.

Secara rinci digambarkan sebagai berikut:

1. Siklus I

a. Perencanaan:

1) Merencanakan model pembelajaran yang akan diterapkan dalam kegiatan pembelajaran Role play pada mata pelajaran Pendidikan Agama Islam materi-materi Sholat berjamaah di kelas VII B SMP Negeri 6 Situbondo

2) Mengembangkan skenario model pembelajaran dengan membuat RPP.

3) Menyusun LOP (Lembar Observasi Peserta Didik)

4) Menyusun kuis (tes) 
5) RPP dan LKS serta perangkat pembelajaran lainnya yang telah dibuat selanjutnya disampaikan kepada guru bidang studi guna untuk dipelajari, didiskusikan dan diperbaiki seperlunya dengan mempertimbangkan waktu yang tersedia

Menyusun soal-soal evaluasi materi sholat jamaah yanga akan diujikan secara tertulis kepada siswa

7) Merencanakan pembentukan kelompok peserta didik yakni kelompok terdiri dari 10 orang diambil secara acak

b. Tahap Pelaksanaan Tindakan

Pada tahap ini pembelajaran disampaikan sesuai metode yang telah direncanakan yaitu metode Role Play dengan mengajak siswa ke Masjid dengan panduan buku paket yang telah disiapkan. Kegiatan pada tahap ini adalah :

1) Siswa telah diberi tugas membaca bacaan bahan ajar di rumah sebelum materi tersebut dibahas maksudnya agar ada babyangan tentang materi yang akan dipelajari sehingga ada kesiapan belajar

2) Guru membagi kelompok yang terdiri dari 10 anak dan masing- masing kelompok terdiri dari anak laki-laki dan perempuan, kemudian setiap kelompok menunjuk 1 anak sebagai imam, 1 anak sebagai muazin, 2 anak sebagai makmum masbuk dan yang lainnya adalah sebagai makmum

3) Setiap kelompok mempunyai tugas untuk memerankan dan mempraktekan sholat berjamaah secara bergantian tentunya tetap dengan bimbingan guru.

4) Siswa yang lain mengamati dan dan mempersiapkan perannya selanjutnya.

5) Guru dan siswa membuat kesimpulan atau melengkapi jawaban siswa.

6) Guru memberikan tugas atau PR secara individual tentang materi pokok yang sedang dipelajari. 
6)

c. Observasi dengan melakukan format observasi

Mengamati proses pelaksanaan permainan Role play yang diperankan oleh siswa menggunakan format observasi dan setelah mengetahui hasilnya kemudian didiskusikan dengan guru untuk memecahkan masalah yang terjadi selama tindakan.

d. Refleksi

1) Menilai hasil tindakan dengan menggunakan format LOP.

2) Melakukan evaluasi tindakan yang telah dilakukan.

3) Melakukan pertemuan untuk membahas hasil evaluasi tentang skenario model pembelajaran, LOP, dan lain-lain.

4) Memperbaiki pelaksanaan tindakan sesuai hasil hasil evaluasi untuk digunakan pada siklus berikutnya.

\section{Siklus II}

Setelah melakukan evaluasi tindakan I, maka dilakukan tindakan II. Peneliti mengamati proses penerapan model pembelajaran Role Play pada mata pelajaran Pendidikan Agama Islam. Langkah-langkah siklus II tersusun seperti siklus I dengan berbagai perubahan sesuai hasil refleksi.

\section{F. Teknik Pengumpulan Data}

1. Sumber Data

Sumber Data penelitian tindakan kelas ini meliputi :

a. Hasil belajar siswa

b. Lembar observasi aktivitas siswa dan guru serta respon siswa dalam kegiatan pembelajaran

c. Lembar kerja Siswa (LKS)

2. Teknik Pengumpulan Data

Teknik yang digunakan untuk mengumpulkan data dari lapangan adalah :

1. Observasi,

2. Tes Tertulis.

3. Metode Dokumenter.

\section{G. Instrumen Penelitian}

Instrumen penelitian meliputi :

1. Skenario pembelajaran berisi langkah pembelajaran tiap siklus

2. Materi dan bentuk tes 
3. Menentukan Tipe Soal

4. Cara Penskoran dan Penilaian

\section{H. Teknik Analisis Data}

Dalam penelitian ini terdapat 2 analisis data yaitu data kuantitatif dan data kualitatif.

\section{Data Kuantitatif}

Rumus yang digunakan untuk mengetahui keberhasilan dan peningkatan secara individu adalah :

$$
\sum^{\underline{b}} N S=\quad \begin{aligned}
& x 100 \% \\
& \sum^{n}
\end{aligned}
$$

Keterangan:

NS : Nilai Peningkatan Hasil Belajar

$\sum^{b} \quad:$ Jumlah Skor jawaban benar tiap siswa

$\sum^{n} \quad$ : Jumlah item soal

Kemudian untuk peningkatan hasil belajar secara klasikal jika 85\% dari seluruh peserta didik dalam kelas telah mencapai nilai 70. Untuk menghitung kriteria peningkatan hasil belajar secara klasikal adalah dengan rumus :

$$
\begin{aligned}
& p=\frac{\sum^{n 1}}{\sum^{n}} x 100 \% \\
& \text { Keterangan : } \\
& \text { P : Nilai Peningkatan hasil Belajar secara klasikal } \\
& \begin{array}{ll}
\sum^{n 1} & : \text { Jumlah siswa tuntas belajar secara klasikal } \\
& : \text { Jumlah total siswa }
\end{array}
\end{aligned}
$$

2. Analisis Kualitatif digunakan oleh peneliti untuk mengetahui peningkatan hasil belajar siswa yang diambil pengamatan dan hasil wawancara 


\section{HASIL PENELITIAN DAN PEMBAHASAN}

Pada Tahap pra siklus terdapat banyak siswa yang tidak tuntas dalam belajarnya yaitu hanya mencapai rata-rata nilai 59 dan hal ini masih sangat jauh dari Kriteria Ketuntasan Minimal (KKM) yang telah ditentukan, yaitu nilai per individu adalah 70 . Setelah dilakukan tindakan siklus 1 menggunakan metode role play oleh peneliti dan observer, maka terjadi peningkatan hasil belajar siswa yang pada tahap pra siklus nilai rata-rata siswa hanya mencapai 59 dan nilai rata-rata klasikal adalah $30 \%$ naik menjadi 71,5 dan nilai rata-rata secara klasikal adalah 66,6\%. Walau telah mengalami peningkatan hasil belajar siswa, namun rata-rata tersebut belum memenuhi standar ketuntasan yang telah ditentukan yaitu nilai rata-rata siswa secara individu adalah 70 dan rata-rata secara klasikal mencapai $85 \%$.

Setelah mengadakan observasi pada siklus 1, maka antara peneliti dan observer berdiskusi untuk memecahkan masalah yang terjadi pada siklus 1 dan merencanakan tindakan untuk pelaksanaan siklus 2, maka dalam pelaksanaan tindakan siklus 2 lebih terkoordinir sehingga pada tahap siklus 2 ini terjadi peningkatan hasil belajar secara maksimal yaitu nilai rata-rata siswa mencapai 80,5 dan rata-rata secara klasikal mencapai 93,3\%. Dalam penelitian ini menunjukkan bahwa metode role play yang diterapkan pada mata pelajaran Pendidikan Agama Islam materi sholat berjamaah berhasil meningkatkan hasil belajar siswa kelas VII B SMP Negeri 6 Situbondo. Adapun data hasil penelitian dari masing-masing siklus akan dipaparkan pada Analisis Hasil Penelitian.

Berdasarkann hasil observasi hasil belajar siswa pra siklus pada siswa kelas VII B masih sangat rendah dari Kriteria Ketuntasan Minimal (KKM) yang telah ditentukan yaitu 70 seperti terlihat pada tabel Rekapitulasi berikut:

Rekapitulasi Hasil Post Tes Pra Siklus

\begin{tabular}{ll}
\hline Hasil Post Tes & Pra Siklus \\
\hline Nilai Tertinggi & 70 \\
\hline Nilai Terendah & 40 \\
\hline Rata-Rata Nilai & 59 \\
\hline Prosentase Ketuntasan Belajar & $30 \%$ \\
\hline
\end{tabular}

Hasil tes akhir yang dilakukan di akhir pembelajaran didapat bahwa rata-rata hasil belajar pada siswa yang berjumlah 30 siswa yang pada tahap pra siklus adalah 59 yang jauh dari rata-rata yang diinginkan yaitu 70. Sedangkan peningkatan hasil 
belajar klasikal adalah $30 \%$ yang berada di bawah standar $85 \%$ dari data yang diperoleh pada tahap pra siklus. Data tersebut dijadikan pertimbangan untuk memecahkan masalah dengan upaya-upaya perbaikan belajar agar hasil belajar siswa dapat meningkat.

Dari refleksi kemudian didiskusikan dengan observer untuk mencari solusi tersebut atau mendiskusikan tentang pendekatan dengan menggunakan pembelajaran role play. Solusi ataupun hasil diskusi tersebut akan diterapkan menjadi sebuah tindakan untuk tahap berikutnya yaitu pada siklus 1 .

\section{Analisis Penelitian Tindakan Kelas Siklus 1}

Penelitian tindakan kelas pada siklus 1 dilaksanakan oleh peneliti sekaligus pengampu mata pelajaran Pendidikan Agama Islam di SMP Negeri 6 Situbondo. Pada siklus 1 ini observasi dilaksanakan di kelas VII B pada tanggal 23 Nopember 2018.

Tindakan tersebut kemudian menjadi alternatif pemecahan masalah. Tindakan tersebut adalah sebagai berikut :

1. Melaksanakan pembelajaran yang ada di kelas dengan pembelajaran role play

2. Meninjau kembali rencana pelaksanaan pembelajaran pada tahap pra siklus

3. Pembelajaran akan lebih ditekankan pada keaktifan siswa sehingga memahami inti peran dan bagi siswa yang tidak bermain peran mengamati jalan cerita dengan membuat catatan dari informasi yang didapat.

4. Setelah simulasi bermain peran selesai, sebelum kelompok yang bermain peran duduk di kursinya masing-masing, siswa yang tidak bermain peran memberikan tanggapannya atas penampilannya.

5. Guru mengajak diskusi para siswa dengan melempar pertanyaan berkaitan dengan materi tersebut.

Dari hasil penelitian tentang meningkatkan hasil belajar melalui pembelajaran Role Play pokok bahasan sholat berjamaah pada siklus 1 siswa kelas VII B SMP Negeri 6 Situbondo diperoleh rekapitulasi hasil pos tes sebagai berikut:

\section{Rekapitulasi Hasil Post Tes Siklus 1}

\begin{tabular}{ll}
\hline Hasil Post Tes & Siklus 1 \\
\hline Nilai Tertinggi & 85 \\
\hline Nilai Terendah & 60 \\
\hline Rata-Rata Nilai & 71,5 \\
\hline Prosentase Keberhasilan Belajar & $66,6 \%$ \\
\hline
\end{tabular}


Berkaitan dengan hasil tes akhir yang dilakukan di akhir pembelajaran pada Siklus 1 didapat bahwa rata-rata hasil belajar pada tahap siklus 1 yaitu 71,5. Sudah terjadi peningkatan hasil belajar siswa pada siklus 1 ini, namun dari data yang diperoleh ada 10 peserta didik yang belum meningkat sedangkan rata-rata hasil belajar klasikal $66,6 \%$ yang berada dibawah standar $85 \%$. Ini menunjukkan penelitian ini belum maksimal dan masih perlu diadakan perbaikan.

Hasil evaluasi siklus 1 ada beberapa catatan diantaranya:

1. Masih ditemukannya siswa yang memanfaatkan kesempatan pembelajaran ini untuk bermain, dibuktikan dengan mereka tidak mengamati kelompok yang sedang melaksanakan peran

2. Ada siswa yang merasa malu untuk melaksanakan peran yang ditujukan kepadanya sehingga saling lempar peran

3. Dalam pelaksanaan peran, masih terdapat siswa yang kurang memahami perannya sehingga menjadi asal-asalan dan bercanda dengan kelompoknya

\section{Analisis Penelitian Tindakan Siklus 2}

Siklus 2 ini dilakukan di kelas VII B Siswa SMP Negeri 6 Situbondo pada tanggal 30 Nopember 2018. Tindakan yang dirumuskan pada siklus 1 di atas akan diterapkan pada siklus 2. Metode yang digunakan pada siklus 2 ini sama dengan tindakan pada siklus 1, yaitu menggunakan metode role play. Langkah perbaikan yang dilakukan antara lain :

1. Sebelum pelaksanaan tindakan, guru memberikan informasi bahwa bagi kelompok yang perannya bagus dan sesuai dengan materi yang diajarkan akan mendapatkan penghargaan atau hadiah. Ini bertujuan agar siswa dapat termotivasi dan serius dalam melaksanakan tugasnya

2. Guru lebih memperhatikan aktivitas siswa yang melakukan peran dan siswa yang mengamati sehingga semua siswa dapat terpantau dan tidak lagi bercanda.

Dari hasil penelitian tentang meningkatkan hasil belajar siswa melalui metode role play pokok bahasan Sholat berjamaah pada siklus 2 siswa kelas VII B SMP Negeri 6 Situbondo diperoleh data rekapitulasi nilai pos tes sebagai berikut :

Rekapitulasi Hasil Post Tes Siklus 2

\begin{tabular}{|c|c|c|}
\hline & Hasil Post Tes & Siklus 2 \\
\hline & Nilai Tertinggi & 100 \\
\hline
\end{tabular}




\begin{tabular}{ll}
\hline Nilai Terendah & 65 \\
\hline Rata-Rata Nilai & 80,5 \\
\hline Prosentase Ketuntasan Belajar & $93,3 \%$ \\
\hline
\end{tabular}

Berkaitan dengan hasil akhir yang dilaksanakan di akhir pembelajaran pada siklus 2 didapat bahwa rata-rata nilai hasil tes pada siklus 2 yaitu 80,5 yang berada di atas standar yang ditentukan yaitu di atas 70 . Dari data yang diperoleh pada tahap siklus 2 yaitu ada 2 peserta didik yang belum berhasil mengalami peningkatan sedangkan rata-rata keberhasilan belajar klasikal adalah 93,3\% yang berada di atas standar $85 \%$. Berbeda dengan penelitian sebelumnya, penelitian pada siklus 1 ini siswa yang belum berhasil ada 10 siswa. Dari 2 siswa yang belum berhasil tersebut, akan kembali dicari permasalahanya, guru dan peneliti melakukan diskusi dan sekaligus mencari pemecahannya.

Keberhasilan pada siklus ini ada beberapa faktor yang menyebabkan meningkatnya hasil belajar siswa, antara lain :

1. Peserta didik lebih termotivasi untuk melaksanakan perannya dalam pembelajaran. Hal ini ditandai dengan siswa kelihatan lebih bersemangat dalam menghayati perannya dan lebih tepat dalam mengerjakan tugas dibandingkan dengan tindakan siklus 1 .

2. Kerja kelompok siswa sudah mulai kompak dan terarah

3. Kelompok yang melakukan peran sudah tidak takut dan malu-malu lagi. Mereka banyak yang tampil berani

4. Siswa sudah lebih memahami materi dan tugasnya dalam melaksanakan peran.

5. Guru selalu memberikan bimbingan dan pengarahan selama pembelajaran

6. Pembelajaran menjadi menyenangkan karena bervariasi dan melibatkan anak secara langsung dan tidak monoton di kelas yang menjenuhkan

\section{Analisis Penelitian Paska Tindakan Pelaksanaan Siklus}

Hasil diskusi pembahasan hasil tindakan dari tahap pra siklus, siklus 1 dan siklus 2 yaitu hasil tes akhir menunjukkan peningkatan dari tahap pra siklus, siklus 1 dan siklus 2 dapat ditunjukkan pada tabel berikut : 


\section{Tabel 4.7 Perbandingan Rata-Rata Tes Akhir dan Prosentase Peningkatan Hasil Belajar Klasikal Pada Tahap Pra Siklus, Siklus 1 dan Siklus 2}

\begin{tabular}{clcc}
\hline No & Pelaksanaan Siklus & Rata-Rata & $\begin{array}{c}\text { Prosentase (\%) } \\
\text { Peningkatanan Hasil } \\
\text { Belajar Klasikal }\end{array}$ \\
\hline 1 & Pra Siklus & 59 & $30 \%$ \\
\hline 2 & Siklus 1 & 71,5 & $66,6 \%$ \\
\hline 3 & Siklus 2 & 80,5 & $93,3 \%$ \\
\hline
\end{tabular}

Dari perolehan hasil belajar siswa pada tahap pra siklus dan siklus 1 terlihat adanya peningkatan rata-rata nilai tes siswa yaitu 71,5 dari tahap pra siklus yang semula 59. Sedangkan pada tahap siklus 2 rata-rata nilai meningkat sebesar 80,5. Dari yang semula yaitu hanya 71,5. Ini menunjukkan bahwa penggunaan metode role play yang dilaksanakan pada tindakan siklus 1 dan siklus 2 menunjukkan peningkatan hasil belajar siswa pada mata pelajaran Pendidikan Agama Islam siswa kelas VIIB SMP Negeri 6 Situbondo.

\section{PENUTUP}

\section{Kesimpulan}

Berdasarkan hasil pembahasan dan penelitian tindakan yang telah peneliti tuangkan dalam penulisan skripsi ini, maka dapat disimpulakan bahwa dalam rangka mencapai tujuan pembelajaran, guru diharapkan menggunakan metode yang tepat dalam pelaksanaan pembelajarannya, tentunya dengan memperhatikan kesesuaian metode pembelajaran dengan materi pelajaran.

Keberhasilan penerapan metode role play yang digunakan pada pelajran Pendidikan Agama Islam khususnya pada materi sholat berjamaah pada siswa kelas VII B SMP Negeri 6 Situbondo terbukti dapat meningkatkan hasil belajar siswa.

Peningkatan hasil belajar siswa dalam pelajaran Pendidikan Agama Islam ditunjukkan pada nilai rata-rata kelas yang pada tindakan pra siklus hanya mencapai nilai rata- rata 59 dan banyak anak yang hasil belajarnya belum meningkat karena KKM yang ditetapkan di madrasah adalah 70 dan kebehasilan secara klasikal hanya 30\%, kemudian dilaksanakan siklus 1 menggunakan metode role play nilai rata-rata kelas naik menjadi 71,5 dan anak yang hasil belajarnya belum meningkat ada 10 siswa dan keberhasilan secara klasikal mencapai 66,6\%. Setelah dilakukan tindakan siklus 2 
ternyata hasil belajar siswa meningkat menjadi rata-rata 80,1 dan keberhasilan secara klasikal menjadi $93 \%$ dari $85 \%$. Ini menunjukkan metode role play yang diterapkan pada mata pelajaran Pendidikan Agama Islam khususnya materi sholat berjamaah dapat meningkatkan hasil belajar siswa.

\section{DAFTAR PUSTAKA}

Aly, Hary Noer. 2000. Watak Pendidikan Islam. Jakarta : Friska Agung Insani. Ambarjaya, Beni S. 2008. Model-Model Pembelajaran Kreatif. Bandung : Tinta Emas.

Asrori, Mohammad. 2008. Penelitian Tindakan Kelas. Bandung : CV Wacana Prima.

Aziz, Moh Saefulloh. 2005. Pendidikan Agama Islam Islam Lengkap : Pedoman Hukum Ibadat Umat

Islam Dengan Berbagai Permasalahannya. Surabaya : Terbit Terang.

Ash Shiddieqy.2001.Teungku Muhammad Hasbi. Pengantar Hukum Islam.

Situbondo : PT Pustaka Rizki Putra.

Ahadiniyati dalam Metode Role Play, http://blogspot2018.com/kamis, 24

Februari 2018

Pendidikan Agama Islam Madrasah Tsanawiyah kelas VII. Depag Provinsi Jawa Tengah (Situbondo : PT Karya Toha Putra, 2004)

Hamali, Oemar k, 2004. Proses Belajar Mengajar. Jakarta : Bumi Aksara

http://indoskripsi.blogspot. Minggu, 20 Maret 2018, Jam 17.00 WIB

http://indoskripsi.blogspot.// Jum'at, 18 Maret 2018. Jam 20.00 WIB Joesoef,

Soelaeman.2002. Konsep Dasar Pendidikan Luar Sekolah,

(Jakarta:Ciputat Press)

Mazayanah, Ulfatul. Prestasi Belajar Pendidikan Agama Islam Kelas I Melalui Metode Demonstrasi

MI Subah Batang Tahun 2009

Poster, Cyril. 2000. Gerakan Menciptakan Sekolah Unggul. Jakarta : Lembaga Indonesia Addaya.

Rasyid, Harun \& Mansur. 2008. Penilaian Hasil Belajar. Bandung : CV Wacana Prima.

Rasyad, Aminuddin.2003. Teori Belajar dan Pembelajaran. Jakarta : UHAMKA Press,

Salasa, A.Ridwan. http://blogspot// Senin, 23 Febrauari 2018.

Sanaky, Hujairah. 2009. Media Pembelajaran. Yogyakarta : Safiria Insania Press. 
Sudrajat. Hasil Belajar SKI melalui Pembelajaran Aktif Role Playing Materi Pokok Dinasti Ayyubiyah pada Siswa kelas IX F MTs Al Ansor Gunung Pati Situbondo Tahun Ajaran 2009/2010.

Sumiati \& Asra. 2008. Metode Pembelajaran. Bandung : CV Wacana Prima. Susilana,

Rudi. 2008. Media Pembelajaran : Hakikat, Pengembangan, Pemanfaatan, dan Penilain. Bandung : CV Wacana Ilmu.

W.J.S. Poerwadarminta.1982. Kamus Umum Bahasa Indonesia, (Jakarta : Balai Pustaka)

Sudjana, Nana.1999. Penilaian Hasil Belajar Mengajar, (Bandung: PT Rosda Karya

Syah, Muhibbin. Psikologi Belajar. (Jakarta : Logos Wacana Ilmu, 2001).

T. Ibrahim.2008. Penerapan Pendidikan Agama Islam untuk kelas VII Madrasah Tsanawiyah. (Solo : PT Tiga Serangkai)

Yamin, Martinis. 1996. Profesionalisme Guru dan Implementaisnya. (Situbondo : PT Karya Toha Putra,) 